\title{
LOCALIZATION AND CHARACTERIZATION OF VASOPRESSIN- BINDING SITES IN THE AMYGDALA OF THE RAT BRAIN ${ }^{1}$
}

\author{
DANIEL M. DORSA, ${ }^{*} \S, \|^{2}$ FRANCES M. PETRACCA, ${ }^{* *}$ DENIS G. BASKIN, $, \S, \uparrow$ AND \\ LAWRENCE E. CORNETT $\ddagger \ddagger$ \\ ${ }^{*}$ Geriatric Research, Education, and Clinical Center, and $\ddagger$ Division of Endocrinology and Metabolism, Veterans Administration \\ Medical Center, and Departments of \$Medicine, || Pharmacology, $₫$ Biological Structure, and ${ }^{* *}$ Psychology, University of \\ Washington, Seattle, Washington 98108 and $\$ \neq D$ Department of Physiology and Biophysics, \\ University of Arkansas for Medical Sciences, Little Rock, Arkansas 72205
}

Received September 2, 1983; Revised January 16, 1984; Accepted January 20, 1984

\begin{abstract}
Putative receptors for arginine ${ }^{8}$-vasopressin (AVP) in rat brain were localized and characterized using autoradiographic and radioligand-binding techniques. When brain slices were incubated with tritium-labeled vasopressin, an intense concentration of binding sites was identified which included the medial aspects of the amygdala. Binding of labeled AVP to membrane preparations from this brain region was saturable, specific, reversible, and of high affinity. An antagonist of the peripheral pressor activity of vasopressin was found to be a potent competitor for binding to this site.
\end{abstract}

Arginine $^{8}$-vasopressin (AVP) is synthesized in hypothalamic neurons which project to the posterior pituitary, as well as to numerous extrahypothalamic brain regions (Farrell et al., 1968; Sterba, 1974; Kozlowski et al., 1976; Swanson, 1977; Buijs et al., 1978; Sofroniew and Weindl, 1982). AVP has been extracted, measured, and chromatographically identified (Glick and Brownstein, 1980; Dorsa and Bottemiller, 1982, 1983) in extrahypothalamic brain tissue.

Central administration of AVP has been reported to influence the regulation of blood pressure (Matsuguchi et al., 1980; Pittman et al., 1982) and body temperature (Kasting et al., 1980), to facilitate memory (deWied, 1977; Van Ree et al., 1978; Kovacs et al., 1979; Koob et al., 1981) and the development of tolerance phenomena (Van Ree et al., 1978), to alter turnover of other CNS transmitters (Tanaka et al., 1977), and to modulate their neurochemical effects (Courtney and Raskind, 1983). In

\footnotetext{
${ }^{1}$ We wish to thank Henderson Mar, Chare Vathanaprida, Elisa Lo, and Rena L. Mooney for technical assistance. Thanks also to Patricia Jenkins and Maxine Cormier for manuscript preparation. We are grateful for the generous supply of labeled vasopressin from Dr. Richard Young of New England Nuclear Corporation. Ms. Petracca was supported by the Graduate School research fund of the University of Washington. This work was supported by the Veterans Administration Research Service, National Institutes of Health Grant NS 2031, University of Arkansas for Medical Sciences Institutional Biomedical Research Support Grant RR05350-20, National Science Foundation Grant ISP 8011447 , and by the University of Washington Diabetes Research Center Grant AM-17047.

${ }^{2}$ To whom correspondence should be addressed at: GRECC/182B, Veterans Administration Medical Center, 1660 South Columbian Way, Seattle, WA 98108.
}

total, a large body of evidence has been accumulating which supports the hypothesis that AVP or a related peptide is a neurotransmitter or neuromodulatory substance. However, until recently, little direct evidence for the existence of receptors for vasopressin in brain tissue has been reported. We have recently presented autoradiographic evidence of the existence of AVP-specific binding sites in the septum (Baskin et al., 1983; van Leeuwen and Wolters, 1983) and ventral forebrain (Baskin et al., 1983) and in the nucleus of the solitary tract (Dorsa et al., 1983) of the rat brain. Yamamura et al. (1983) have also reported AVP-binding sites in the magnocellular nuclei of the hypothalamus. Preliminary reports of AVP-binding sites in subcellular particulate fractions (Pearlmutter et al., 1983) and membrane preparations (Dorsa et al., 1983) obtained from various brain regions have recently appeared. In the present study, we report localization of AVP-binding sites in amygdalar region of the rat brain and characterization of an AVPspecific receptor in membrane preparations from this region of the brain.

\section{Materials and Methods}

Preparation of brain tissue slices. Long-Evans rats ( 180 to $200 \mathrm{gm}$ ) were sacrificed by decapitation, and their brains were rapidly removed, mounted on brass cryostat tissue platforms, and then frozen on CO-ice. Serial cryostat sections $(10 \mu \mathrm{m})$ were thaw mounted on gelatincoated microscope slides (Young and Kuhar, 1979; Herkenham and Pert, 1982) with adjacent serial sections mounted on separate slides. The slides were then frozen at $-70^{\circ} \mathrm{C}$ and stored ( 2 to 3 weeks maximum) until use. 
AVP binding to tissue slices. For assays of binding of avp to tissue slices, slides containing tissue slices were thawed to room temperature and placed flat on moist paper towels in a plastic tray. The tissue slices were covered with $200 \mu \mathrm{l}$ of incubation medium containing $100 \mathrm{~mm}$ Tris- $\mathrm{HCl}, \mathrm{pH} 8.0,10 \mathrm{mg}$ of $\mathrm{MgCl}_{2}, 1 \%$ bovine serum albumin, $0.5 \mathrm{mg} / \mathrm{ml}$ of bacitracin, and $100 \mathrm{kalli}-$ krine inhibitory units (KIU)/ml of aprotinin (Sigma) (Dorsa et al., 1983). The incubation medium contained $5 \times 10^{-9}$ M $\left[{ }^{3} \mathrm{H}\right]$ arginine ${ }^{8}$-vasopressin $\left(\left[{ }^{3} \mathrm{H}\right] \mathrm{AVP}\right.$ ) (specific activity $42.1 \mathrm{Ci} / \mathrm{mmol}$, New England Nuclear) or a mixture of $\left[{ }^{3} \mathrm{H}\right] \mathrm{AVP}$ and $1 \times 10^{-6} \mathrm{M}$ unlabeled AVP. The trays were covered during incubation to minimize evaporation and were incubated at room temperature for 30 min. Time course studies had shown that maximum specific binding occurs by $30 \mathrm{~min}$. Slides were then individually drained of excess incubation medium by tilting them and allowing incubation medium to run onto the towel. They were then placed in plastic slide racks and transferred sequentially through two buffer rinses of $30 \mathrm{sec}$ each. The rinse consisted of $10 \mathrm{~mm}$ Tris- $\mathrm{HCl}, \mathrm{pH}$ $8.0,1 \mathrm{mM} \mathrm{MgCl} 2$, and $0.1 \%$ bovine serum albumin at $0^{\circ} \mathrm{C}$. Slide-mounted tissue sections were immediately prepared for autoradiography by drying the sections with a stream of cool air and were stored in a vacuum desiccator at $0^{\circ} \mathrm{C}$ for $24 \mathrm{hr}$. Sections were then placed in contact with tritium-sensitive LKB Ultrofilm in an $\mathrm{x}$-ray cassette, exposed for 1 month at $22^{\circ} \mathrm{C}$, and developed in D19 for $4 \mathrm{~min}$.

Membrane preparations. Brains were rapidly removed from 120 decapitated 2-month-old Sprague-Dawley rats and placed in ice-cold $1.0 \mathrm{mM}$ Tris- $\mathrm{HCl}, 2.0 \mathrm{mM} \mathrm{MgCl}$, $1.0 \mathrm{~mm}$ dithiothreitol (DTT), $0.1 \mathrm{~mm}$ phenylmethylsulfonylfluoride (PMSF), $\mathrm{pH}$ 7.4. Tissue, including the amygdala and surrounding cortical structures, was removed and was separated randomly into four groups. Tissue was homogenized with a Tekmar (model SDT) homogenizer at a setting of 80 for $4 \mathrm{sec}$. The resulting homogenate was centrifuged at $600 \times g$ for $10 \mathrm{~min}$, and the pellet was discarded. The supernatant was centrifuged at $30,000 \times g$ for $20 \mathrm{~min}$, and the pellet, a partially purified membrane preparation, was washed and centrifuged a second time. The membranes were then resuspended in $0.25 \mathrm{M}$ sucrose, $50 \mathrm{mM}$ Tris- $\mathrm{HCl}, 1.0 \mathrm{mM}$ DTT, $0.1 \mathrm{~mm}$ PMSF, $\mathrm{pH} 7.4$, quick frozen in liquid nitrogen, and stored at $-80^{\circ} \mathrm{C}$. Under these conditions, the $\left[{ }^{3} \mathrm{H}\right]$ AVP-binding site was stable for up to 6 months, with no loss of specific binding compared to fresh membranes. Protein was determined by the method of Bradford (1976) with bovine serum albumin as the standard.

$\left[{ }^{3} H\right] A V P$-binding assay in membrane preparations. The $\left[{ }^{3} \mathrm{H}\right] A V P$-binding assays were performed at a volume of $250 \mu \mathrm{l}$ in polypropylene tubes $(12 \times 75 \mathrm{~mm})$. [ $\left.{ }^{3} \mathrm{H}\right]$ AVP was diluted in $236 \mathrm{~mm} \mathrm{NaCl}, 10 \mathrm{mM} \mathrm{KCl}, 10 \mathrm{~mm}$ $\mathrm{MgCl}_{2}, 2 \mathrm{~mm}$ EGTA, $20 \mathrm{~mm}$ HEPES, $\mathrm{pH}$ 7.4, containing $20 \%$ ethanol and $10 \mathrm{mg} / \mathrm{ml}$ of bovine serum albumin and was added to assay tubes in a $25-\mu l$ volume. Peptides were prepared in the same buffer, with the ethanol omitted. These solutions were added to assay tubes in $25-\mu \mathrm{l}$ volumes. Bacitracin $(1.0 \mathrm{mg} / \mathrm{ml})$ and aprotinin $(2000$ $\mathrm{KIU} / \mathrm{ml}$ ) were added in a $10-\mu \mathrm{l}$ volume. Partially purified membrane preparations, suspended in $236 \mathrm{mM} \mathrm{NaCl}, 10$ $\mathrm{mM} \mathrm{KCl}, 10 \mathrm{~mm} \mathrm{MgCl}_{2}, 20 \mathrm{~mm}$ HEPES, $\mathrm{pH}$ 7.4, were added to assay tubes in a $190-\mu$ l volume to initiate the assay. The incubation was carried out at $25^{\circ} \mathrm{C}$ for $45 \mathrm{~min}$ and was terminated by the addition of $5 \mathrm{ml}$ of $236 \mathrm{mM}$ $\mathrm{NaCl}, 10 \mathrm{mM} \mathrm{KCl}, 10 \mathrm{~mm} \mathrm{MgCl}_{2}, 20 \mathrm{mM}$ HEPES, $\mathrm{pH}$ 7.4 , were added to assay tubes in a $190 \mu \mathrm{l}$ volume to initiate the assay. The incubation was carried out at $25^{\circ} \mathrm{C}$ for $45 \mathrm{~min}$ and was terminated by the addition of $5 \mathrm{ml}$ of $236 \mathrm{mM} \mathrm{NaCl}, 10 \mathrm{~mm} \mathrm{KCl}, 10 \mathrm{mM} \mathrm{MgCl}, 2 \mathrm{mM}$ EGTA, $20 \mathrm{~mm}$ HEPES, $\mathrm{pH} 7.4$, at $4^{\circ} \mathrm{C}$. The contents of the tubes were filtered immediately through Whatman GF/ C glass fiber filters on a Yeda filtration manifold. Filters were presoaked in buffer containing $10 \mathrm{nM}$ AVP. Filters were washed with an additional $15 \mathrm{ml}$ of buffer, dried by high vacuum, and placed in scintillation vials containing Hydrofluor (National Diagnostics). Radioactivity was determined by liquid scintillation counting (Packard model $460 \mathrm{C}$ ) at $26 \%$ efficiency.

Synthetic peptides. $\left[{ }^{3} \mathrm{H}\right]$ Phenylalanyl-arginine ${ }^{8}$-vasopressin was a gift of Dr. D. Young and Dr. S. R. Wan of New England Nuclear Corp. Unlabeled arginine ${ }^{8}$-vasopressin, oxytocin (OXY), [des-glycinamide] ${ }^{9}$-arginine ${ }^{8}$ vasopressin (DG-AVP), and pressinoic acid were gifts from Dr. H. Greven and H. Rigter of Organon B.V. (Oss, Holland). The vasopressin pressor antagonist $[1-(\beta$-mercepto- $\beta, \beta$-cyclopentamethylene propionic acid), 2-(0methyl) tyrosine]-arginine ${ }^{8}$-vasopressin (Kruszynski et al., 1980) (M-AVP, antagonist) and lysine ${ }^{8}$-vasopressin (LVP) were obtained from Peninsula Laboratories (Palo Alto, CA). Cyclic somatostatin was a gift from Dr. Jay Taborsky of the Seattle Veterans Administration Medical Center.

Dala unalysis. Data derived from saturation experiments was analyzed using the nonlinear model fitting program LIGAND (Munson and Rodbard, 1980) to arrive at estimates for the following parameters: dissociation constant, binding site concentration, and nonspecific binding. Inhibitory constants $\left(K_{i}\right)$ were calculated from the formula $K_{i}=\mathrm{IC}_{50} /\left(\mathrm{I}+(\mathrm{AVP}) / K_{d}\right)$ described by Cheng and Prusoff (1973). The $\mathrm{IC}_{50}$ is defined as the concentration of peptide that reduces specific bound $\left[{ }^{3} \mathrm{H}\right]$ AVP by $50 \%$, (AVP) is the concentration of $\left[{ }^{3} \mathrm{H}\right] \mathrm{AVP}$ in the assay tube, $K_{d}$ is the $\left[{ }^{3} \mathrm{H}\right] \mathrm{AVP}$ dissociation constant determined from saturation experiments. All data are reported as means $\pm \mathrm{SE}$.

\section{Results}

Localization of $\left[{ }^{3} H\right] A V P$ binding. Figure 1 shows the results obtained on tritium-sensitive film exposed to brain slices which had been incubated with $5 \mathrm{~nm}\left[{ }^{3} \mathrm{H}\right]$ AVP. In sections between 4 and $5 \mathrm{~mm}$ anterior to the vertical zero plane of Pelligrino et al. (1981), an intense concentration of binding sites was apparent in the region of the amygdala. These binding sites were evident primarily in the central nucleus, medial nucleus, and in other sections (not shown), which also included the basolateral nucleus of the amygdala. Addition of $5 \mu \mathrm{M}$ unlabeled AVP to the incubation medium abolished binding of $\left[{ }^{3} \mathrm{H}\right] \mathrm{AVP}$ to the amygdala.

Binding kinetics. $\left[{ }^{3} \mathrm{H}\right] \mathrm{AVP}$ bound rapidly to amygdala membranes, reaching equilibrium within $30 \mathrm{~min}$ at $25^{\circ} \mathrm{C}$, and binding was stable for at least $30 \mathrm{~min}$ (Fig. 2). The observed rate constant ( $K_{\text {obs }}$ ) was calculated to be 0.072 $\min ^{-1} .\left[{ }^{3} \mathrm{H}\right] \mathrm{AVP}$ dissociated from the binding site with a 

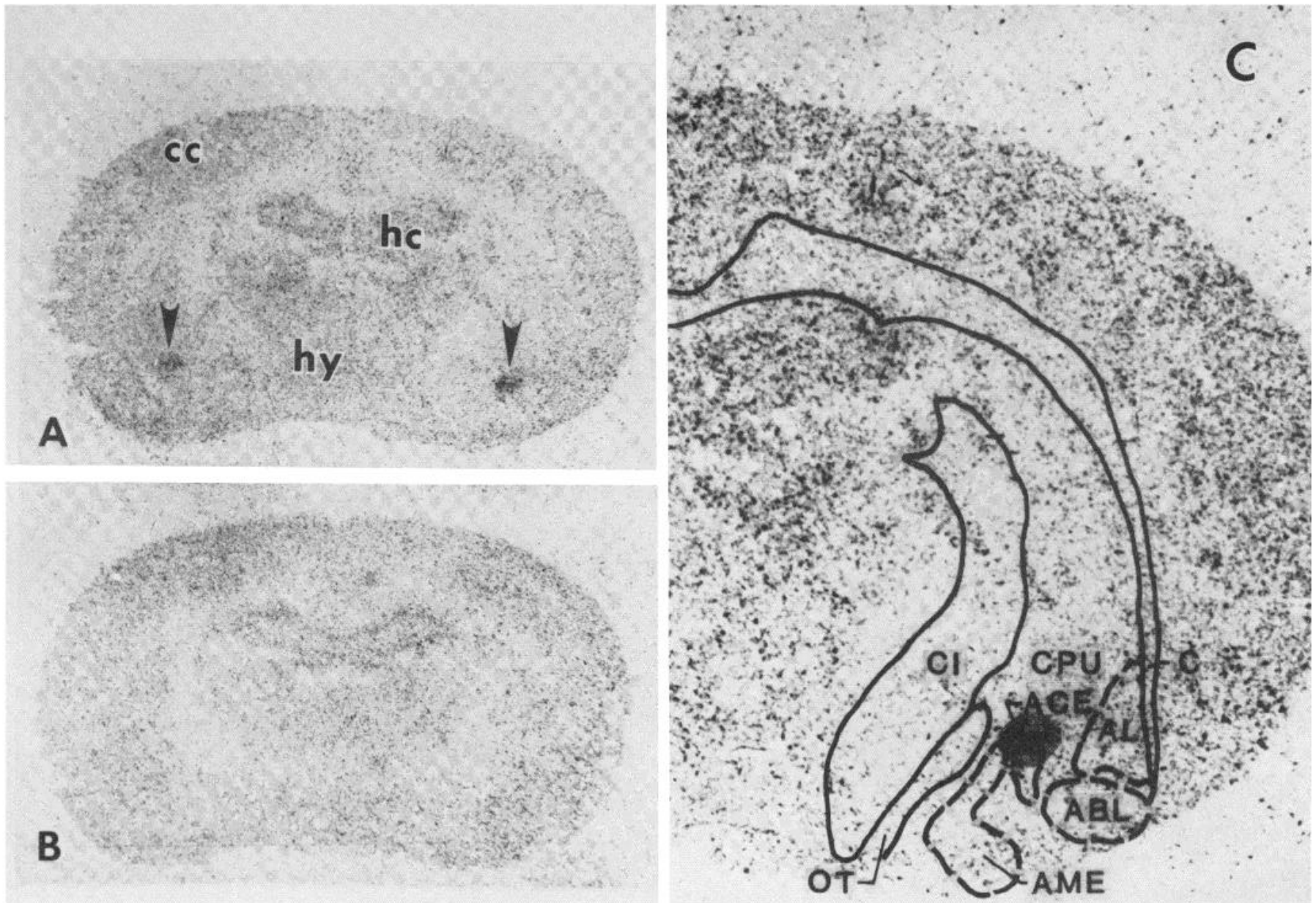

Figure 1. Localization of $\left[{ }^{3} \mathrm{H}\right] \mathrm{AVP}$-binding sites in the amygdala of the rat brain. A, The distribution of radioactivity as revealed by LKB Ultrofilm exposed for 1 month to a brain section which had been incubated with $5 \mathrm{nM}\left[{ }^{3} \mathrm{H}\right] \mathrm{AVP}$. $B$, Adjacent section which was incubated with $5 \mathrm{nM}\left[{ }^{3} \mathrm{H}\right]$ AVP plus $5 \mu \mathrm{M}$ unlabeled AVP. The arrow points indicate regions of specific binding of AVP in the medial aspects of the amygdala. $c c$, cerebral cortex; $h c$, hippocampus; $h y$, hypothalamus. $C$, The image in $A$ was enlarged to coincide with the appropriate section represented in the atlas of Pelligrino et al. (1981) $(-0.6 \mathrm{~mm}$ from bregma). Selected features of the amygdala and other structures are shown. $C$, corpus callosum; $C I$, internal capsule; $O T$, optic tract; $C P U$, caudate-putamen; $A M E$, medial nucleus of the amygdala; $A L$, lateral nucleus; $A C E$, central nucleus; $A B L$, lateral part of the basal nucleus. The region of highest specific AVP binding is depicted in the half-tone.

half-time of dissociation of approximately $25 \mathrm{~min}$ at $25^{\circ} \mathrm{C}$ and $10 \mathrm{~min}$ at $37^{\circ} \mathrm{C}$ following a 100 -fold dilution (Fig. 3 ). The dissociation of $\left[{ }^{3} \mathrm{H}\right] \mathrm{AVP}$ was not affected by the presence of unlabeled AVP (10 nM) in the dilution buffer (Fig. 3). The calculated dissociation rate constant $\left(K_{\text {off }}\right)$ at $25^{\circ} \mathrm{C}$ was $0.071 \pm 0.02 \min ^{-1}(n=3)$. Using the association rate constant $\left(K_{\text {on }}\right)$ and $K_{\text {off }}$ (see legends to Figs. 2 and 3 for explanation of calculations) we calculated a dissociation constant $\left(K_{d}\right)$ of $0.15 \mathrm{nM}$, which is in good agreement with the dissociation constant determined from equilibrium experiments (see below).

Binding site saturation. Binding of $\left[{ }^{3} \mathrm{H}\right] \mathrm{AVP}$ to amygdala membranes was linear with respect to protein over a range of 125 to $375 \mu \mathrm{g}$ of protein/assay tube (Fig. 4). Analysis of saturation data with ligand (Munson and Rodbard, 1980) resulted in a best fit with a single site model (Fig. 5). The $\left[{ }^{3} \mathrm{H}\right]$ AVP dissociation constant was $0.93 \pm 0.35 \mathrm{nM}(n=4)$, and the binding site concentra- tion was $32.9 \pm 5.1 \mathrm{fmol} / \mathrm{mg}$ of protein $(n=4)$. Specific binding of $\left[{ }^{3} \mathrm{H}\right] \mathrm{AVP}$ at $1.0 \mathrm{nM}$, as defined by $10.0 \mu \mathrm{M}$ unlabeled AVP, was $47 \%$ (range $=35$ to $66 \%, n=4$ ).

Specificity of the binding site. Specificity of the $\left[{ }^{3} \mathrm{H}\right]$ AVP-binding site was determined by testing a series of peptides for their ability to compete with $\left[{ }^{3} \mathrm{H}\right] \mathrm{AVP}$ for binding to amygdala membranes. The rank order of potency of peptides competing for the $\left[{ }^{3} \mathrm{H}\right] \mathrm{AVP}$-binding site was (1- $\beta$-mercapto- $\beta, p$-cyclopentamethylene proprionic acid)-2-(o-methyl) tyrosin arginine ${ }^{8}$-vasopressin (M-AVP) $\geq$ arginine $^{8}$-vasopressin $>$ lysine ${ }^{8}$-vasopressin $\gg$ oxytocin $=[\text { desglycinamide }]^{9}$ arginine ${ }^{8}$-vasopressin $>$ pressinoic acid (Fig. 6, Table I).

\section{Discussion}

While a large body of evidence has been accumulating that vasopressin is a CNS transmitter or neuromodulator, the presence of putative receptors for AVP in brain 


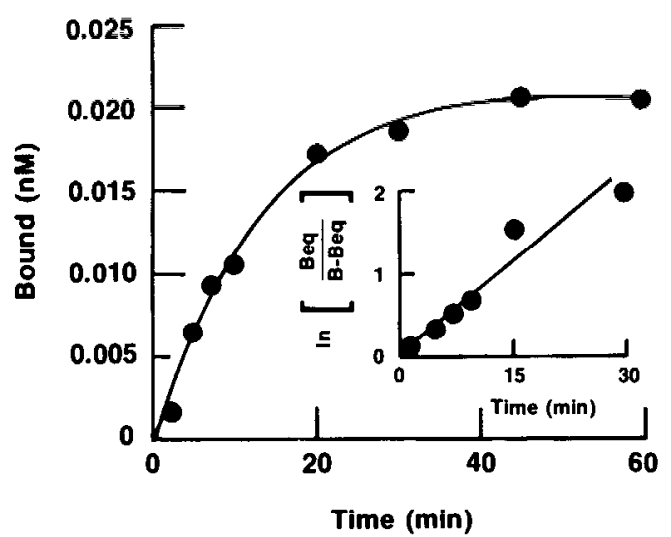

Figure 2. Time course of $\left[{ }^{3} \mathrm{H}\right] \mathrm{AVP}$ binding to amygdala membranes. Partially purified membranes $(0.96 \mathrm{mg} / \mathrm{ml})$ were incubated with $1.4 \mathrm{nM}\left[{ }^{3} \mathrm{H}\right] \mathrm{AVP}$ at $25^{\circ} \mathrm{C}$ for the indicated time. Bound and free $\left[{ }^{3} \mathrm{H}\right] \mathrm{AVP}$ were separated by filtration through Whatman GF/C filters. Each point represents the mean of duplicate determinations from a representative experiment. Inset, Pseudo-first-order association rate plot $\left(B\right.$, bound $\left[{ }^{3} \mathrm{H}\right]$ AVP at indicated time; $B e q$, bound $\left[{ }^{3} \mathrm{H}\right]$ AVP at equilibrium). The observed rate constant $\left(K_{\text {obs }}\right)$ was determined from the slope of the line. The $K_{\text {on }}$ was obtained using the equation $K_{\text {obs }}$ $=\left(K_{\text {on }}\right)(L)+K_{\text {off }}$ where $L=$ the concentration of $\left[{ }^{3} \mathrm{H}\right] \mathrm{AVP}$ used in the experiment. The reaction was considered pseudofirst order since the concentration of $\left[{ }^{3} \mathrm{H}\right] \mathrm{AVP}$ was much higher than the concentration of receptors and, therefore, did not change appreciably during the experiment. The rate constant for dissociation $\left(K_{\text {off }}\right)$ determined in a separate experiment (see Fig. 2) was used to solve the above equation for the rate constant of association $\left(K_{\mathrm{on}}\right)$ (Williams and Lefkowitz, 1978).

tissue has only recently been reported. Autoradiographic evidence for the existence of AVP-specific binding sites in the septum and ventral forebrain (Baskin et al., 1983; van Leeuwen and Wolters, 1983), in the nucleus of the solitary tract (Dorsa et al., 1983), and in the magnocellular areas of the hypothalamus (Yamamura et al., 1983) of the rat brain has recently appeared. These areas are known to contain either cell bodies or fibers of neurons which immunostain for AVP or its neurophysin (Farrell et al., 1968; Sterba, 1974; Kozlowski et al., 1976; Swanson, 1977; Buijs et al., 1978; Sofroniew and Weindl, 1982). Vasopressin-like immunoreactivity also is measurable by radioimmunoassay in extracts of these microdissected areas (Dorsa and Bottemiller, 1982, 1983).

In the present study, we have provided evidence for the existence of high affinity receptors for AVP and related peptides in membranes prepared from brain tissue which included the amygdala and surrounding cortical structures. $\left[{ }^{3} \mathrm{H}\right]$ AVP binding to brain tissue slices was highly localized to the medial aspects of the amygdala, a parallel distribution to that reported for AVPneurophysin-containing neurons (Buijs et al., 1978; Sofroniew and Weindl, 1982).

Binding of $\left[{ }^{3} \mathrm{H}\right] \mathrm{AVP}$ to membrane preparations which included amygdalar tissue was found to be saturable and of high affinity. $\left[{ }^{3} \mathrm{H}\right] \mathrm{AVP}$ binding was only partially reversible at $25^{\circ} \mathrm{C}$ with approximately $50 \%$ of initially bound $\left[{ }^{3} \mathrm{H}\right] \mathrm{AVP}$ dissociating within $2 \mathrm{hr}$. The rate of dissociation was not affected by the addition of $10 \mathrm{nM}$

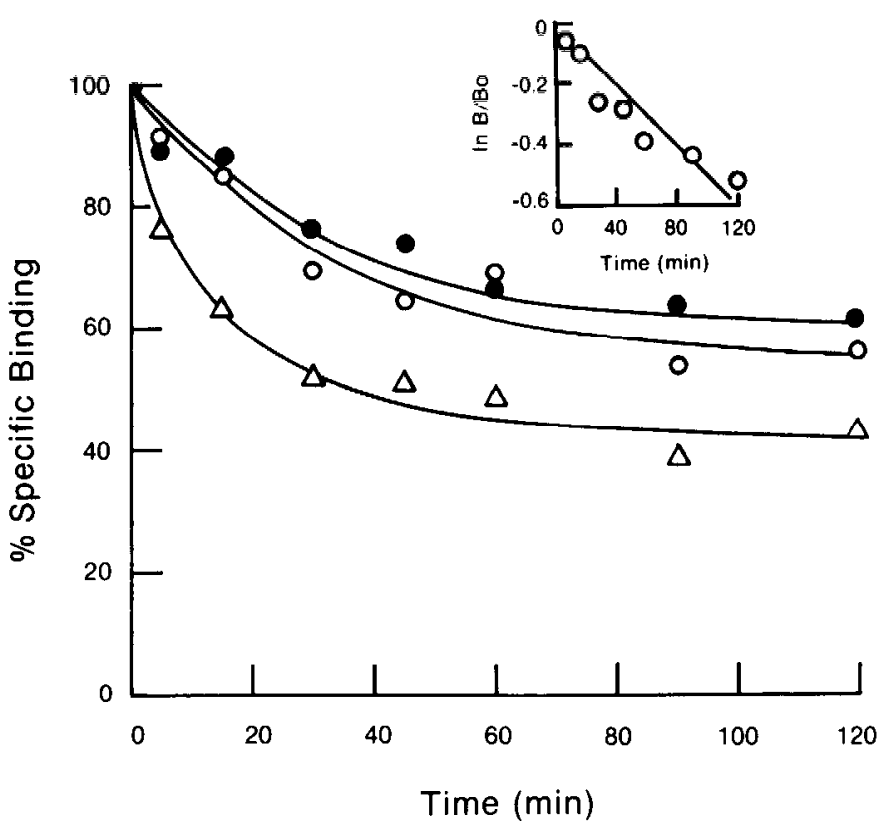

Figure 3. Reversibility of $\left[{ }^{3} \mathrm{H}\right]$ AVP binding to amygdala membranes. Partially purified membranes $(2.4 \mathrm{mg} / \mathrm{ml})$ were incubated with $1.4 \mathrm{nM}\left[{ }^{3} \mathrm{H}\right] \mathrm{AVP}$ for $45 \mathrm{~min}$ at $25^{\circ} \mathrm{C}$. Aliquots of $50 \mu \mathrm{l}$ were made and were diluted with $5.0 \mathrm{ml}$ of $236 \mathrm{mM}$ $\mathrm{NaCl}, 10 \mathrm{~mm} \mathrm{KCl}, 10 \mathrm{mM} \mathrm{MgCl}_{2}, 2 \mathrm{~mm}$ EGTA, $20 \mathrm{~mm}$ HEPES, $\mathrm{pH} 7.4$, and the incubation was continued at either $25^{\circ} \mathrm{C}(\mathrm{O})$, $25^{\circ} \mathrm{C}$ in the presence of $10 \mathrm{nM} \operatorname{AVP}(-)$, or $37^{\circ} \mathrm{C}(\triangle)$. Each point represents the mean of duplicate determinations of bound $\left[{ }^{3} \mathrm{H}\right]$ AVP from a representative experiment. Inset, First-order dissociation rate plot of data from dilution at $25^{\circ} \mathrm{C}$ experiment. The rate constant for dissociation $\left(K_{\text {off }}\right)$ was determined by linear regression.

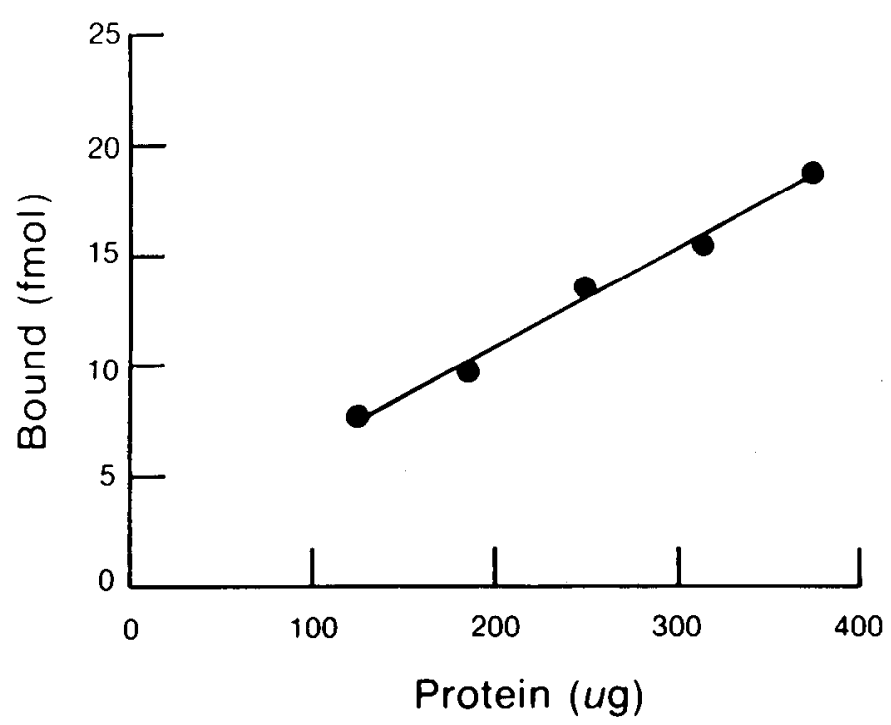

Figure 4. Effect of protein concentration on specific binding of $\left[{ }^{3} \mathrm{H}\right] \mathrm{AVP}$. Binding assays were carried out in duplicate as described in the text using $2.0 \mathrm{nM}\left[{ }^{3} \mathrm{H}\right] \mathrm{AVP}$ in the presence and absence of $0.1 \mu \mathrm{M}$ unlabeled AVP. Protein concentration ranged from 125 to $375 \mu \mathrm{g} /$ assay tube. Data are plotted as micrograms of protein per assay tube versus specifically bound $\left[{ }^{3} \mathrm{H}\right]$ AVP. Analysis by linear regression yielded a correlation coefficient of 0.997 . 


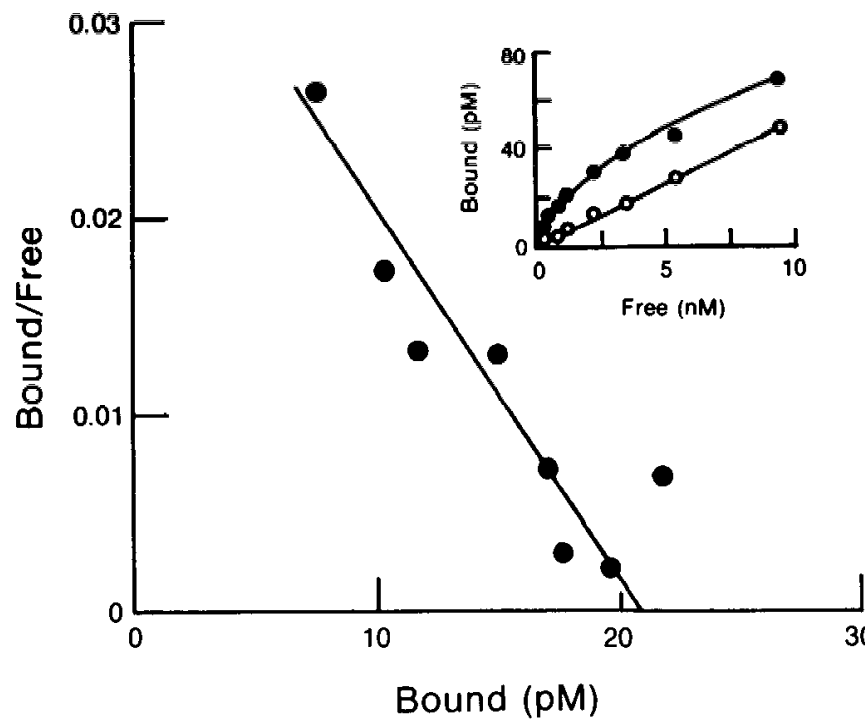

Figure 5. Scatchard analysis of [ $\left.{ }^{3} \mathrm{II}\right]$ AVP binding to amygdala membranes. Partially purified membranes $(0.76 \mathrm{mg} / \mathrm{ml})$ were incubated with increasing concentrations of $\left[{ }^{3} \mathrm{H}\right] \mathrm{AVP}(0.25$ to $8.3 \mathrm{nM}$ ). Specific binding was determined as described under "Materials and Methods." Each point represents the mean of duplicate determinations from a representative experiment. Inset, Direct plot of total binding (O) and nonspecific binding defined with $0.1 \mu \mathrm{M}$ unlabeled AVP (O).

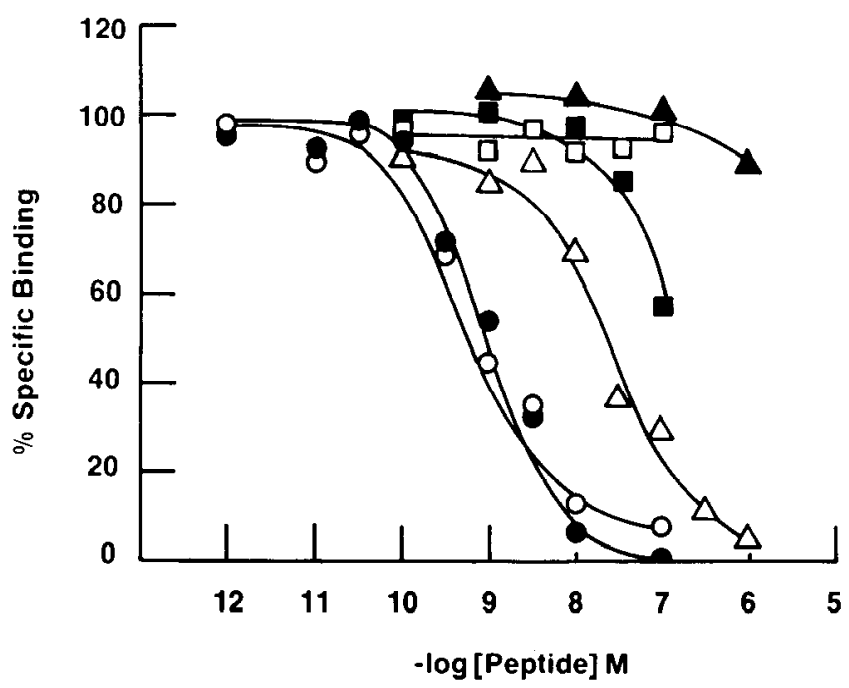

Figure 6. Inhibition of $\left[{ }^{3} \mathrm{H}\right] \mathrm{AVP}$ binding to amygdala membranes by selected peptides. Partially purified membranes $(1.15$ $\mathrm{mg} / \mathrm{ml}$ ) were incubated with 1.3 to $1.9 \mathrm{nM}\left[{ }^{3} \mathrm{H}\right] \mathrm{AVP}$ and increasing concentrations of either arginine ${ }^{8}$-vasopressin $(\boldsymbol{\bullet})$, (1- $(\beta$-mercapto- $\beta, \beta$-cyclopentamethylene proprionic acid), 2 -( $O$-methyl $)$-tyrosine $)$-arginine ${ }^{8}$-vasopressin $(O), \quad[$ des-glycinamide $]^{9}$-arginine ${ }^{8}$-vasopressin $(\square)$, oxytocin $(\square)$, lysine ${ }^{8}$-vasopressin $(\Delta)$, or pressinoic acid $(\Delta)$. One hundred percent specific binding was defined as $\left[{ }^{3} \mathrm{H}\right] \mathrm{AVP}$ bound in the absence of unlabeled AVP, and $0 \%$ specific binding was defined as $\left[{ }^{3} \mathrm{H}\right]$ AVP bound in the presence of $0.1 \mu \mathrm{M} \mathrm{AVP}$.

AVP during the dissociation phase, indicating an absence of cooperative binding interactions. Dissociation of $\left[{ }^{3} \mathrm{H}\right]$ AVP was accelerated at $37^{\circ} \mathrm{C}$, although $40 \%$ of initially bound $\left[{ }^{3} \mathrm{H}\right] \mathrm{AVP}$ did not dissociate within $2 \mathrm{hr}$. An ap-
TABLE $\overline{\mathrm{I}}$

Inhibition constants for selective peptides in amygdala membranes Competition experiments were performed and data were analyzed as described under "Materials and Methods." Inhibition constants $\left(K_{i}\right)$ were calculated from the formula $\left.K_{i}=\mathrm{IC}_{60} /(\mathrm{I}+\mathrm{AVP}) / K_{d}\right)$ and are reported as either the mean $\pm \mathrm{SE}(n=3)$ or the mean $(n=2)$.

\begin{tabular}{|c|c|c|}
\hline \multirow[t]{2}{*}{ Peptide } & \multicolumn{2}{|c|}{ Inhibition Constant } \\
\hline & $\mathrm{nM}$ & $n$ \\
\hline Arginine $^{8}$-vasopressin & $0.43 \pm 0.09$ & 3 \\
\hline $\begin{array}{l}(\mathrm{I}=\beta \text {-mercapto } \beta, \beta \text {-cyclopentamethylene } \\
\text { proprionic acid) } 2-(O \text {-methyl }) \text { tyrosine }) \text { - } \\
\text { arginine }{ }^{8} \text {-vasopressin }\end{array}$ & $0.32 \pm 0.06$ & 3 \\
\hline Lysine ${ }^{8}$-vasopressin & $12.33 \pm 2.26$ & 3 \\
\hline Des-glycinamide $^{9}$-arginine ${ }^{8}$-vasopressin & $>100$ & 2 \\
\hline Oxytocin & $>100$ & 2 \\
\hline Pressinoic acid & $>1000$ & 2 \\
\hline
\end{tabular}

parently nonreversible component of $\left[{ }^{3} \mathrm{H}\right] \mathrm{AVP}$ binding to membranes of rat anterior pituitary gland recently has been observed (Lutz-Butcher and Koch, 1983). The nature of this nonreversible component of $\left[{ }^{3} \mathrm{H}\right] \mathrm{AVP}$ binding is currently unknown, although we believe it may represent association of $\left[{ }^{3} \mathrm{H}\right] \mathrm{AVP}$ with nonsaturable sites.

The dissociation constant observed in brain tissue is slightly lower than that which we have measured in rat kidney (e.g., 1 to $3 \mathrm{~nm}$ ) (Dorsa et al., 1983), and well below the reported $K_{d}$ for AVP receptors from rat vascular smooth muscle (e.g., $5 \mathrm{nM}$ ) (Schiffrin and Genest, 1983). Michell et al. (1979) proposed two isotypes of the vasopressin receptor termed $V_{1}$ and $V_{2} . V_{1}$ receptors were associated with calcium as a second messenger, while $V_{2}$ receptors were associated with cyclic AMP as a second messenger. The AVP receptor in renal tissue appears to be linked to adenylate cyclase (Bockaert et al., 1973; Butlen et al., 1978; Sawyer et al., 1981a; Dorsa et al., 1983), while hepatic AVP receptors are not (Michell et al., 1979; Jard, 1983). In addition, differences exist in potency of synthetic vasopressin agonists and antagonists that preferentially act as either pressor agents (Sawyer et al., 1981) or as antidiuretic agents (Butlen et al., 1978; Sawyer et al., 1982b; Crause and Fahrenholz, 1982).

In the present study, we have identified a putative AVP receptor in brain tissue which appears to differ from the renal AVP receptor in specificity. In the amygdala, the pressor antagonist M-AVP (Kruszynski et al., 1980) was even more potent than synthetic AVP in displacing $\left[{ }^{3} \mathrm{H}\right]$ AVP from binding, whereas it is much less potent than AVP at the renal receptor when evaluated on tissue slice or membrane preparations (Dorsa et al., 1983). In addition, we (Dorsa et al., 1983) and others (Courtney and Raskind, 1983) have recently reported that AVP fails directly to stimulate cyclic AMP accumulation in membrane preparations from the brainstem and other regions of the rat brain. Whether the amygdala receptor is distinct from pressor and/or hepatic receptors remains to be determined.

The present results suggest that brain receptors for AVP may be yet another subtype of a large family of 
recognition sites for AVP. The work of de Wied et al. (de Wied, 1977; de Wied and Versteeg, 1979) has also suggested that CNS vasopressin receptors are pharmacologically distinct since des-glycinamide ${ }^{9}$-arginine ${ }^{8}$-vasopressin, which is devoid of peripheral pressor and antidiuretic activity, retains the potency of AVP in preventing extinction of a conditioned avoidance response. In the present study, DG-AVP was found to be a poor competitor for binding to the amygdalar receptor, as it has been shown to be in kidney (Dorsa et al., 1983) and pressor (Schiffrin and Genest, 1983) receptor assay systems.

What role, if any, AVP plays in the functions of the amygdala is uncertain. Gillis and Cain (1983) recently reported that Brattleboro rats, which lack the ability to synthesize AVP, are resistant to seizure induction following amygdaloid and pyriform cortex kindling. These investigators suggested that amygdaloid AVP may be an important link in seizure induction. In addition, administration of the pressor antagonist M-AVP blocks convulsions induced by intracranial AVP administration (Burnard et al., 1983). The latter finding is interesting considering the high apparent affinity of this antagonist for the AVP-binding sites we have examined in the present study.

In summary, we have localized AVP-specific binding sites in the amygdala of the rat brain which have pharmacological characteristics of AVP receptors. These data also raise the possibility that brain AVP receptors may differ significantly from those which have been previously described in the periphery and may be yet another subtype of receptor for this neuropeptide.

\section{References}

Baskin, D. G., F. Petracca, and D. M. Dorsa (1983) Autoradiographic localization of specific binding sites for $\left[{ }^{3} \mathrm{H}\right]$ arginine ${ }^{8}$-vasopressin in the septum of the rat brain with tritium-sensitive film. Eur. J. Pharmacol. 90: 155-157.

Bockaert, J., C. Roy, R. Rajerison, and S. Jard (1973) Specific binding of $\left[{ }^{3} \mathrm{H}\right]$ lysine-vasopressin to pig kidney plasma membranes. J. Biol. Chem. 248: 5922-5931.

Bradford, M. M. (1976) A rapid sensitive method for the quantitation of microgram quantities of protein utilizing the principle of protein-dye binding. Anal. Biochem. 72: 248254.

Buijs, R. N., D. F. Swaab, J. Dogerom, and F. W. van Leewen (1978) Intra- and extrahypothalamic vasopressin and oxytocin pathways in the rat. Cell. Tissue Res. 186: 423-433.

Burnard, D. M., Q. J. Pittman, and W. L. Veale (1983) Prevention of vasopressin-induced convulsions by an antivasopressor antagonist. Can. J. Physiol. Pharmacol. 61: Aiii.

Butlen, D., G. Guillon, R. M. Rajerison, S. Jard, W. H. Sawyer, and M. Manning (1978) Structural requirements for activation of vasopressin-sensitive adenylate cyclase, hormone binding, and antidiuretic actions: Effects of highly potent analogues and competitive inhibitors. Mol. Pharmacol. 14: 1006-1017.

Cheng, X., and W. H. Prusoff (1973) Relationship between the inhibition constant $\left(K_{i}\right)$ and the concentration of inhibitor which causes a 50 percent inhibition $\left(\mathrm{IC}_{50}\right)$ of an enzymatic reaction. Biochem. Pharmacol. 22: 3099-3108.

Courtney, N., and M. R. Raskind (1983) Vasopressin affects adenylate cyclase activity in rat brain: A possible neuromodulator. Life Sci. 32: 591-596.
Crause, P., and F. Fahrenholz (1982) Affinities of reactive vasopressin analogues for bovine antidiuretic receptor. Mol. Cell. Endocrinol. 28: 529-541.

de Wied, D. (1977) Peptides and behavior. I ife Sci. 20; 192204.

deWied, I), and D. H. (G, Versteeg (1979) Neurohypophyseal principles and memory. Fed. Proc. 38: 2348-2354.

Dorsa, D. M., and L. A. Bottemiller (1982) Age-related changes of vasopressin content of microdissected areas of the rat brain. Brain Res. 242: 151-156.

Dorsa, D. M., and L. A. Bottemiller (1983) Vasopressin-like peptides in the rat brain: Immunologic and chromatographic behavior and their response to water deprivation. Regul. Peptides 6: 393-403.

Dorsa, D. M., L. A. Majumdar, F. M. Petracca, D. G. Baskin, and L. E. Cornett (1983) Characterization and localization of ${ }^{3} \mathrm{H}$-arginine ${ }^{8}$-vasopressin binding to rat kidney and brain tissue. Peptides 4: 699-706.

Farrell, G., L. F. Fabre, and E. Rauschkolb (1968) The neurohypophysis. Annu. Rev. Physiol. 30: 557-588.

Gillis, S., and G. S. Cain (1983) Amygdala and pyriform cortex kindling in vasopressin deficient rats (Brattleboro strain). Brain Res. 271: 375-378.

Glick, S. M., and M. J. Brownstein (1980) Vasopressin content of rat brain. Life Sci. 27: 1103-1110.

Herkenham, M., and C. B. Pert (1982) Light microscopical localization of brain opiate receptors: A general autoradiographic method which preserves tissue quality. J. Neurosci. 2: $1129-1149$.

Jard, S. (1983) Vasopressin receptors in mammals: Relation to cyclic AMP-dependent and cyclic AMP-independent transduction mechanisms. Curr. Top. Membranes Transport 18: $255-285$.

Kasting, N. W., W. C. Veal, and K. E. Cooper (1980) Convulsive and hypothermic effects of vasopressin in the brain of the rat. Can. J. Physiol. Pharmacol. 58: 316-319.

Koob, G. F., M. Le Moal, O. Gaffori, M. Manning, W. H. Sawyer, J. Rivier, and F. E. Bloom (1981) Arginine vasopressin and a vasopressin antagonist peptide: Opposite effects on extinction of active avoidance in rats. Regul. Peptides 2: 153163.

Kovacs, G. L., B. Bohus, D. H. G. Versteeg, E. R. de Kloet, and D. de Wied (1979) Effect of oxytocin and vasopressin on memory consolidation: Sites of action and catecholaminergic correlates after microinjection into limbic midbrain structures. Brain Res. 175: 304-314.

Kozlowski, G. P., M. S. Browfield, and G. Hostetter (1976) Neurosecretory supply to extrahypothalamic structures: Choroid plexus, circumventricular organs and limbic system. In Evolutionary Aspects of Neuroendocrinology, VII International Symposium on Neurosecretion, Leningrad, A. L. Polenow, W. Bargmann, and B. Scharreer, eds., pp. 78-86, Springer-Verlag, Berlin.

Kruszynski, M., B. Cammek, M. Manning, J. Seto, J. Haldar, and W. H. Sawyer (1980) [1-(3-Mercapto- $\beta, \beta$-cyclopenta methylene propionic acid], 2-[O-methyl tyrosine)] Arg vasopressin and [1-( $\beta$-mercapto- $\beta, \beta$-cyclopenta methylene propionic acid) Arg-vasopressin, two highly potent antagonists of the vasopressor response to arginine vasopressin. J. Med. Chem. 23: 364-368.

Lutz-Bucher, B., and B. Koch (1983) Characterization of specific receptors for vasopressin in the pituitary gland. Biochem. Biophys. Res. Commun. 115: 492-498.

Matsuguchi, H., P. G. Schmid, F. J. Gorden, and A. K. Johnson (1980) Increases in blood pressure and heart rate after vasopressin administration by microinjection into the area of nucleus tractus solitarius of rats. Physiologist 23: 29-33. 
Michell, R. H., C. J. Kirk, and M. M. Billah (1979) Biochem. Soc. Trans. 7: 861-865.

Munson, P. V., and D. Rodbard (1980) Ligand: A versatile computerized approach for characterization of ligand-binding systems. Anal. Biochem. 107: 220-239.

Pearlmutter, A. F., M. G. Constantini, and B. Loeser (1983) Characterization of ${ }^{3} \mathrm{H}$-AVP binding sites in particulate preparations of rat brain. Peptides 4: 335-341.

Pelligrino, L. J., A. S. Pelligrino, and A. J. Cushman (1981) A Stereotaxic Atlas of the Rat Brain, Plenum Press, New York.

Pittman, Q. J., D. Lawrence, and L. McLean (1982) Central effects of arginine vasopressin on blood pressure in rats. Endocrinology 110: 1058-1060.

Sawyer, W. H., Z. Grozonka, and M. Manning (1981a) Neurohypophyseal peptides: Design of tissue specific agonists and antagonists. Mol. Cell. Endocrinol. 22: 717-134.

Sawyer, W. H., P. K. T. Pang, J. Seto, M. McEnroe, B. Lammek, and M. Manning (1981b) Vasopressin analogs that antagonize antidiuretic responses to the antidiuretic hormone. Science 212: 49-51.

Schiffrin, E. L., and J. Genest (1983) Vasopressin binding to the rat mesenteric artery. Endocrinology 113: 409-411.

Sofroniew, M. W., and A. Weindl (1982) Central nervous system distribution of vasopressin, oxytocin, and neurophysin. In Endogenous Peptides and Learning and Memory Proc-

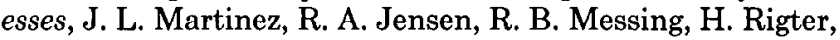
and J. L. McGaugh, eds., pp. 328-369, Academic Press, New York.
Sterba, G. (1974) Ascending neurosecretory pathways of the peptidergic type. In Neurosecretion: The Final Neuroendocrine Pathway, F. Knowles and L. Vollrath, eds., pp. 38-47, Springer-Verlag, Berlin.

Swanson, L. W. (1977) Immunohistochemical evidence for a neurophysin-containing autonomic pathway arising in the paraventricular n. of the hypothalamus. Brain Res. 128: 346353.

Tanaka, M., E. R. de Kloet, D. de Wied, and D. H. G. Versteeg (1977) Arginine ${ }^{8}$-vasopressin affects catecholamine metabolism in spccific brain nuclei. Life Sci. 20: 1799 1808.

van Leeuwen, F. W., and P. Wolters (1983) Light microscopic autoradiographic localization of $\left[{ }^{3} \mathrm{H}\right]$ arginine-vasopressin binding sites in the rat brain and kidney. Neurosci. Lett. 41 : 61-66.

Van Ree, J. M., B. Bohus, D. Versteeg, and D. de Wied (1978) Neurophypophyseal principles and memory processes. Biochem. Pharmacol. 27: 1793-1800.

Williams. L. T., and R. J. Lefkowitz (1978) Adrenergic Pharmacology, pp. 27-41, Raven-Press, New York.

Yamamura, H. I., K. W. Gee, R. E. Brinton, T. P. Davis, M. Hadley, and J. K. Wamsley (1983) Light microscopic autoradiographic visualization of $\left[{ }^{3} \mathrm{H}\right]$ arginine vasopressin binding sites in rat brain. Life Sci. 32: 1919-1924.

Young, W. S., and M. Kuhar (1979) A new method for receptor autoradiography: $\left[{ }^{3} \mathrm{H}\right]$ Opioid receptors in rat brain. Brain Res. 197: 255-270. 